\title{
Kinetics and equilibrium studies for the removal of heavy metals in both single and binary systems using hydroxyapatite
}

\author{
S. T. Ramesh $\cdot$ N. Rameshbabu $\cdot$ R. Gandhimathi $\cdot$ \\ P. V. Nidheesh • M. Srikanth Kumar
}

Received: 4 November 2011/Accepted: 6 March 2012/Published online: 21 March 2012

(c) The Author(s) 2012. This article is published with open access at Springerlink.com

\begin{abstract}
Removal of heavy metals is very important with respect to environmental considerations. This study investigated the sorption of copper $(\mathrm{Cu})$ and zinc $(\mathrm{Zn})$ in single and binary aqueous systems onto laboratory prepared hydroxyapatite (HA) surfaces. Batch experiments were carried out using synthetic HA at $30{ }^{\circ} \mathrm{C}$. Parameters that influence the adsorption such as contact time, adsorbent dosage and $\mathrm{pH}$ of solution were investigated. The maximum adsorption was found at contact time of 12 and $9 \mathrm{~h}, \mathrm{HA}$ dosage of 0.4 and $0.7 \mathrm{~g} / \mathrm{l}$ and $\mathrm{pH}$ of 6 and 8 for $\mathrm{Cu}$ and $\mathrm{Zn}$, respectively, in single system. Adsorption kinetics data were analyzed using the pseudofirst-, pseudosecondorder and intraparticle diffusion models. The results indicated that the adsorption kinetic data were best described by pseudosecond-order model. Langmuir and Freundlich isotherm models were applied to analyze adsorption data, and Langmuir isotherm was found to be applicable to this
\end{abstract}

S. T. Ramesh $(\bowtie) \cdot$ R. Gandhimathi · P. V. Nidheesh ·

M. Srikanth Kumar

Department of Civil Engineering,

National Institute of Technology,

Tiruchirappalli 620 015, Tamilnadu, India

e-mail: stramesh@nitt.edu

R. Gandhimathi

e-mail: rgmathii@nitt.edu

P. V. Nidheesh

e-mail: nidheeshpv129@gmail.com

M. Srikanth Kumar

e-mail: m_kumar225@yahoo.co.in

N. Rameshbabu

Department of Metallurgical and Materials Engineering,

National Institute of Technology, Tiruchirappalli 620015 ,

Tamilnadu, India

e-mail: nrb@nitt.edu adsorption system, in terms of relatively high regression values. The removal capacity of HA was found to be $125 \mathrm{mg}$ of $\mathrm{Cu} / \mathrm{g}, 30.3 \mathrm{mg}$ of $\mathrm{Zn} / \mathrm{g}$ in single system and $50 \mathrm{mg}$ of $\mathrm{Cu} / \mathrm{g}, 15.16 \mathrm{mg}$ of $\mathrm{Zn} / \mathrm{g}$ in binary system. The results indicated that the HA used in this work proved to be effective material for removing $\mathrm{Cu}$ and $\mathrm{Zn}$ from aqueous solutions.

Keywords Hydroxyapatite · Adsorption · Isotherm · Kinetics

\section{Introduction}

The heavy metals are of great concern because of their extreme toxicity even at low concentration and the tendency to accumulate in the food chain (Mohan and Singh 2002). The removal of toxic heavy metals from industrial wastewaters is one of the most important issues of environmental remediation. Heavy metals such as $\mathrm{Pb}, \mathrm{Cd}, \mathrm{Cu}$, $\mathrm{Zn}, \mathrm{Hg}, \mathrm{Cr}$, and $\mathrm{Ni}$ are the main contaminants of surface water, groundwater, and soils. The main sources of these elements are metal plating industries, abandoned disposal sites, and mining industries (Mulligan et al. 2001). Heavy metal contamination of waters and soils is particularly dangerous to the living organisms. Heavy metals are major pollutants in marine, ground, industrial and even treated wastewaters (Valdman et al. 2001). The presence of toxic heavy metals in water has several problems with animals, plants and human being (Ozer and Pirinççi 2006).

$\mathrm{Cu}$ and $\mathrm{Zn}$ are among the most toxic metals affecting the environment. The primary sources of $\mathrm{Cu}$ in industrial wastewater are metal-process pickling baths and plating baths. $\mathrm{Cu}$ may also be present in wastewater from a variety of chemical manufacturing processes employing $\mathrm{Cu}$ salts 
or a $\mathrm{Cu}$ catalyst (Eckenfelder 2000). Many studies have shown that these metals are toxic even at very low concentrations. However, these metals have many applications in the industry. For example, $\mathrm{Cu}$ is known as an excellent conductor of electricity, widely used in the electrical industry in all gauges of wires for circuitry. $\mathrm{Cu}$ is also utilized in analytical reagents, in paints for ship keels and in electroplating. $\mathrm{Cu}$ acts as an irritant to the skin causing itching and dermatitis, and may cause keratinization of the hands and soles of the feet (Sitting 1981). $\mathrm{Zn}$ is often found in effluents discharged from industries involved in acid mine drainage, galvanizing plants, natural ores and municipal wastewater treatment plants and is not biodegradable and travels through the food chain via bioaccumulation (King et al. 2008). Therefore, a systematic study of the removal of $\mathrm{Cu}$ and $\mathrm{Zn}$ from wastewater is of considerable significance from an environmental point of view.

Many researchers have conducted studies on various methods for the removal of heavy metals from waters and wastewaters. Conventional physicochemical methods such as electrochemical treatment, ion-exchange, precipitation, reverse osmosis, evaporation and oxidation/reduction for heavy metal removal from waste streams are expensive, not eco-friendly and inefficient for metal removal from dilute solutions containing from 1 to $100 \mathrm{mg} / \mathrm{l}$ of dissolved metal (Montazer-Rahmati et al. 2011). Efficient and environmental friendly technologies are, therefore, need to be developed to reduce heavy metal contents in wastewaters to acceptable levels at inexpensive costs (Saeed and Iqbal 2003). One alternate effective process is the adsorption which relies on the utilization of solid adsorbents with no chemical degradation. It is attractive due to its merits of effectiveness, efficiency and free sludge (Chu and Chen 2002). Among the various adsorbents, adsorption onto activated carbon (granular or powdered) is widely used; there is still a need to develop low cost and easily available adsorbents for the removal of heavy metal ions from the aqueous environment (Chauhan and Sankararamakrishnan 2011). Hence in recent years, research has been focused on the use of various low cost adsorbents including calcined phosphate (Aklil et al. 2004), activated hazelnut shell ash (Bayrak et al. 2006), orange peel (Feng et al. 2011), black gram husk (Saeed and Iqbal 2003), Coir pith (Ramesh et al. 2011a, 2011b), plants (Benhima et al. 2008; Chiban et al. 2009, 2011a, b, c, 2012), etc.

The present study focuses on the removal of $\mathrm{Cu}$ and $\mathrm{Zn}$ from aqueous solutions by hydroxyapatite (HA) $\left[\mathrm{Ca}_{10}\right.$ $\left.\left(\mathrm{PO}_{4}\right)_{6}(\mathrm{OH})_{2}\right] . \quad \mathrm{HA}$ is a unique inorganic compound because of its high removal capacity for divalent heavy metal ions, and synthetic HA has been used to remove heavy metals such as $\mathrm{Pb}$ (Suzuki et al. 1984; Hashimoto and Sato 2007; Mavropoulos et al. 2002; Shashkova et al. 1999), Zn (Corami et al. 2007), Cd (Lusvardi et al. 2002),
Cr (Shashkova et al. 1999), Fe (Shashkova et al. 1999), Oxovanadium (Vega et al. 2009) and $\mathrm{Cu}$ (Corami et al. $2007,2008)$ from aqueous solutions.

\section{Materials and methods}

Preparation and characterization of HA nanoparticles

The HA synthesized in the laboratory was used as adsorbent for this study. Analytical grade calcium hydroxide $\left[\mathrm{Ca}(\mathrm{OH})_{2}\right.$, E. Merck, Germany], and di-ammonium hydrogen phosphate [DAP, $\left(\mathrm{NH}_{4}\right)_{2} \mathrm{HPO}_{4}$, E. Merck, Germany], were used for the preparation of HA nanoparticles. The amount of the reactants was calculated based on the $\mathrm{Ca} / \mathrm{P}$ molar ratio $(10 / 6=1.67)$. The 0.3 -M DAP solution was added to the $0.3-\mathrm{M}$ calcium hydroxide aqueous suspension in $5 \mathrm{~min}$ under high-speed stirring conditions. This solution with a $\mathrm{pH}$ of 11 (Orion 3 star, Thermo electron, USA) was immediately subjected to the microwave irradiation for about $30 \mathrm{~min}$ in a domestic microwave oven (Samsung India, $2.45 \mathrm{GHz}, 850 \mathrm{~W}$ power). The mixing, crystallization of the HA and its aging occurs under the microwave irradiation in a shorter period. The product obtained after filtration was oven-dried at $70{ }^{\circ} \mathrm{C}$ for overnight and the cake obtained after drying was powdered with agate mortar and pestle.

The X-ray diffraction is carried out for the HA powder particles using a Rigaku Ultima III X-ray diffractometer with $\mathrm{Cu} \mathrm{K} \mathrm{K}_{\alpha 1}$ radiation $(\lambda=1.54056 \AA)$ over the $2 \theta$ range of $20-60^{\circ}$, using a step size of $0.02^{\circ}$ and step time of $4 \mathrm{~s}$. The functional groups present in the synthesized HA were ascertained by Fourier transform infrared spectroscopy (FTIR, Perkin Elmer, Spectrum One, USA) over the region $400-4,000 \mathrm{~cm}^{-1}$ in pellet form for the powder samples of $1 \mathrm{mg}$ mixed with spectroscopic grade $\mathrm{KBr}$ (Merck) of $200 \mathrm{mg}$. Spectra were recorded at $4 \mathrm{~cm}^{-1}$ resolution, averaging 80 scans. The size and morphological features of synthesized HA powders were analyzed by transmission electron microscope (TEM, Philips, CM12 STEM, Netherlands). For TEM analysis, the powder sample was ultrasonically dispersed in ethanol to form dilute suspensions, and then few drops were deposited on the carboncoated $\mathrm{Cu}$ grids.

Preparation of stock solutions

Metal salts of $\mathrm{CuSO}_{4} \cdot 5 \mathrm{H}_{2} \mathrm{O}$ for $\mathrm{Cu}$ and $\mathrm{ZnCl}_{2}$ for $\mathrm{Zn}$ were used to prepare metal ion solutions. The stock solutions $(1,000 \mathrm{mg} / \mathrm{l})$ were prepared by dissolving appropriate amounts of metal salts in doubly distilled water. The working solutions (each $10 \mathrm{mg} / \mathrm{l}$ ) were prepared by diluting the stock solutions to appropriate volumes. 


\section{Sorption experiments}

Batch kinetic study was conducted with the known dosage of adsorbent $(0.006 \mathrm{~g}$ of HA) for the $100 \mathrm{ml}$ of metal ion $(10 \mathrm{mg} / \mathrm{l})$ solution. The samples were shaken at an agitation rate of $250 \mathrm{rpm}$. The samples were taken out at 1,3,6, $9,12,24,36$ and $48 \mathrm{~h}$. The sorbent solution mixtures were then centrifuged for $5 \mathrm{~min}$ and the supernatant was analyzed for the metal ion concentration using Thermo Scientific S-series model flame atomic absorption spectrometer. The sorption studies were carried out by shaking a series of bottles containing different amounts of HA dosage $(0.002-0.3 \mathrm{~g})$ in $100 \mathrm{ml}$ of metal ions solution prepared in the laboratory. The samples were stirred at room temperature at $250 \mathrm{rpm}$ for equilibrium time. The effect of solution $\mathrm{pH}$ on $\mathrm{Cu}$ and $\mathrm{Zn}$ removal was studied over a $\mathrm{pH}$ range of 2-10 which was adjusted with $0.1 \mathrm{~N}$ $\mathrm{HNO}_{3}$ or $0.1 \mathrm{~N} \mathrm{NaOH}$ at the beginning of the experiment and not controlled during the experiment. Optimized dose of HA powder was added into metal solution and shaked at $250 \mathrm{rpm}$, for equilibrium time. The amount of each metal ion adsorbed onto the HA was calculated by the difference between the content of the metal ion in the influent solution and that of the effluent solution, corrected with the blank, and it is expressed in percentage. After the removal of heavy metals was completed, the HA samples were separated by filtering and dried at $120{ }^{\circ} \mathrm{C}$ in an oven. FTIR analyses were carried out on the dried samples to find out modifications in the functional groups after adsorption process.

\section{Results and discussion}

\section{Characterization of HA nanoparticles}

In order to characterize HA, XRD, FTIR and TEM analysis were carried out on synthesized HA. A typical XRD pattern of the HA sample is shown Fig. 1. X-ray diffraction (XRD) analysis confirmed the mineralogical identity and the crystallinity of HA. The XRD peaks were markedly boarder, which suggested that HA particles were nano-sized and correspond to the hexagonal HA crystal (JCPDS 9-432). The presence of other calcium phosphate phases was not detected. The peak boarding of the XRD reflection was used to estimate the crystallite size in a direction perpendicular to the crystallographic plane based on Scherer's formula as given Eq. 1 (Gupta et al. 2006).

Crystal size $=\frac{0.9 \lambda}{\beta \operatorname{Cos} \theta}$

Where $\lambda$ is the wave length of $\mathrm{X}$ rays, $\beta$ is full width at half height of peak in radians and $\theta$ is the angle of

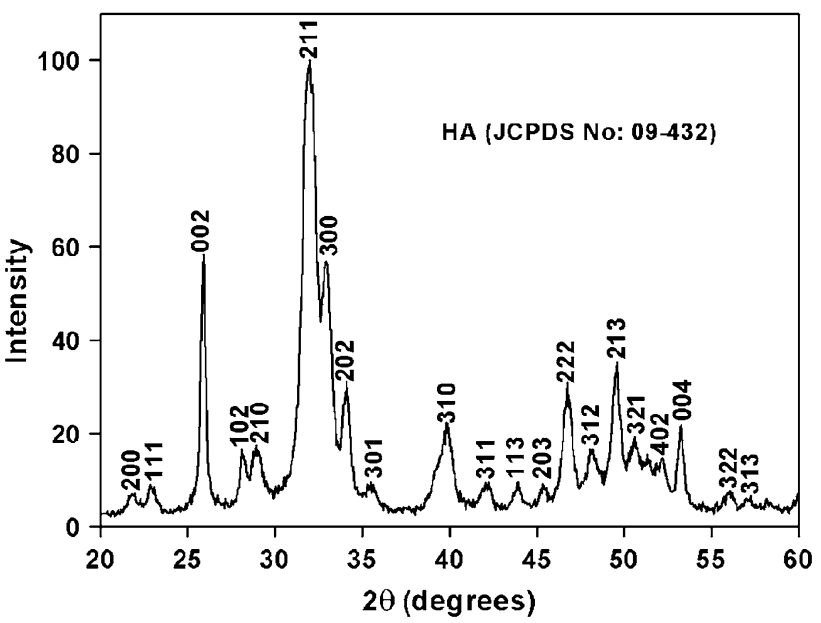

Fig. 1 X-ray diffraction pattern of HA adsorbent in as-synthesized condition

diffraction. The diffraction peak at $25.9^{\circ}$ was considered for calculation of the crystal size; since it is sharper and isolated from others. This peak assigns to $\left(\begin{array}{lll}0 & 0 & 2\end{array}\right)$ Miller's plane family and shows the crystal growth along $c$ axis of the HA crystalline structure. The estimated crystallite size was $28 \mathrm{~nm}$ for the HA sample.

The TEM morphology of HA samples in as-synthesized condition is shown in Fig. 2. The HA particles are found to be of nano-sized with needle-like morphology, with width ranging from $15-20 \mathrm{~nm}$ and length around $50-60 \mathrm{~nm}$, the size comparable to that of bone apatite. The infrared spectra of HA before adsorption in the 4,000-400 $\mathrm{cm}^{-1}$ region is shown in Fig. 3. Hydroxyl stretch is observed at $3,560 \mathrm{~cm}^{-1}$ (Manjubala et al. 2011) in the spectra of HA powder. Peaks in the region of $1,650-1,300 \mathrm{~cm}^{-1}$ are due to $\mathrm{v}_{3}$ vibrational mode carbonate ion (Rehman and Bonfield 1997). These carbonate bands in the region of $1,650-1,300 \mathrm{~cm}^{-1}$ are assigned to surface carbonate ions, rather than to carbonate ions in the lattice of phosphate ions (Rehman and Bonfield 1997). Hydroxyapatite has three sites for $\mathrm{v}_{3}$ vibrational mode centerd at 1,608, 1,422 and $1,360 \mathrm{~cm}^{-1}$. Phosphate $\mathrm{v}_{4}$ band is present in the region of 660 and $520 \mathrm{~cm}^{-1}$ and is a well-defined and sharp band, observed in the HA. A single intense $v_{3}$ band is present at $1,056 \mathrm{~cm}^{-1}$ (Rehman and Bonfield 1997). The FTIR spectrum of $\mathrm{HA}$ after interaction with $\mathrm{Cu}, \mathrm{Zn}$ and Binary $(\mathrm{Cu}-\mathrm{Zn})$ metals are also shown in Fig. 3. FTIR spectra of the solid residues after adsorption are comparable to those of the original HA, suggesting no other phases formed during the heavy metal sorption. Compared with the FTIR spectra before and after adsorption of $\mathrm{Cu}$ and $\mathrm{Zn}$ in single and binary system, there were clear band shifts and \% transmittance increase for HA (Table 1). The changes mainly occur in the $\mathrm{OH}^{-}$and $\mathrm{CO}_{3}{ }^{2-}$ groups of $\mathrm{HA}$ that had bound heavy metals. 


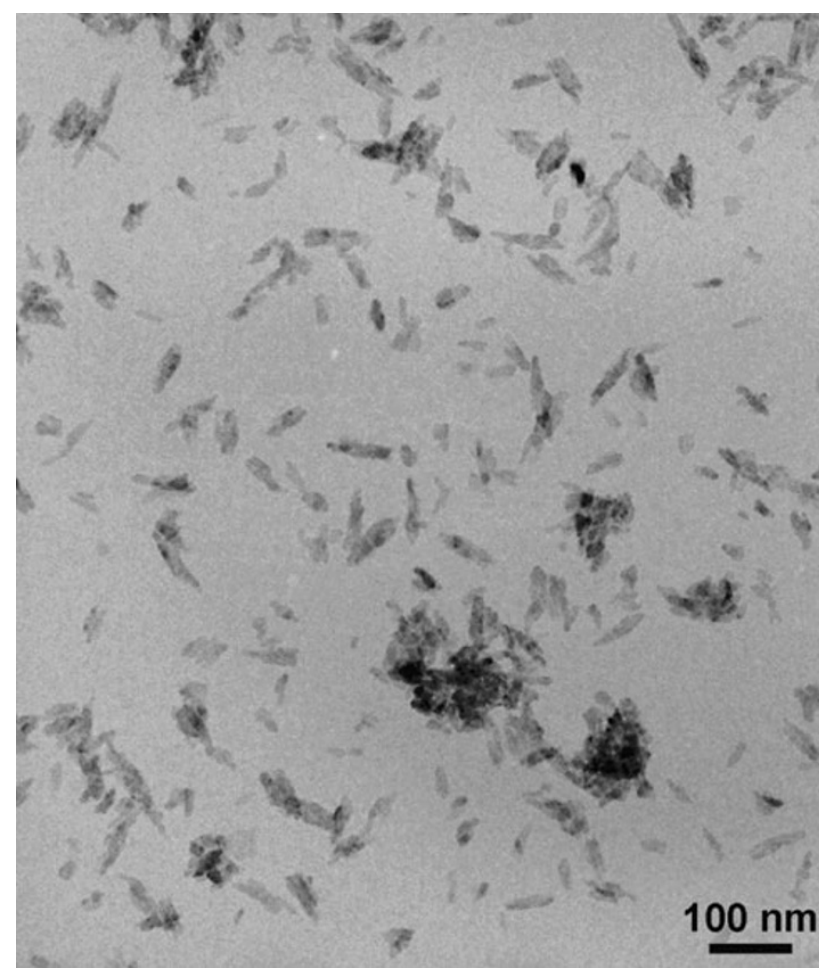

Fig. 2 TEM bright field image of HA

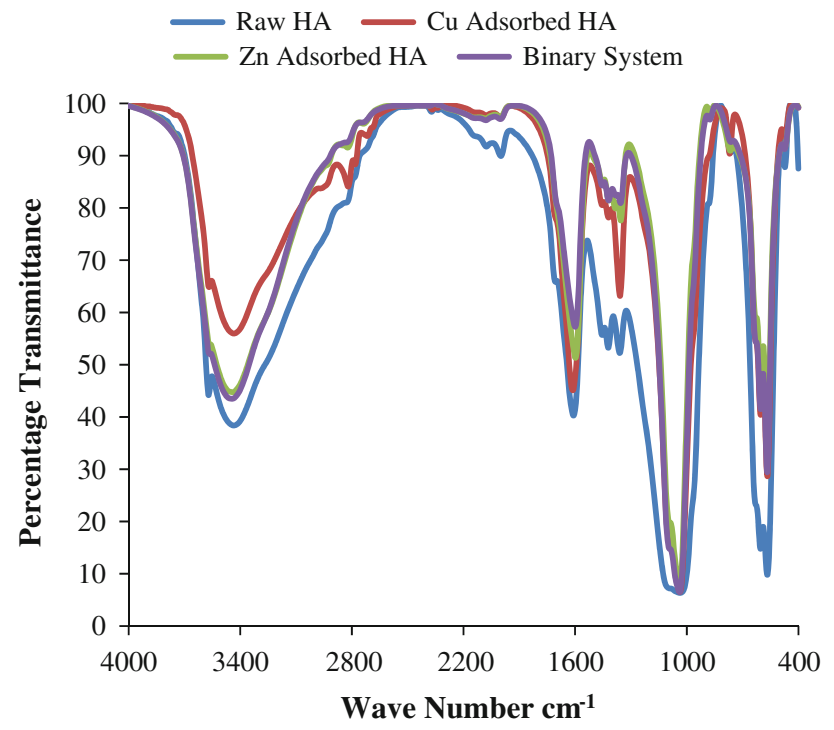

Fig. 3 FTIR spectra for removal of $\mathrm{Cu}$ and $\mathrm{Zn}$ by HA

\section{Effect of contact time}

Metal ion uptake capacities were determined as a function of time to determine an optimum contact time for the adsorption of heavy metal ions on HA. The variation of percentage of adsorbed metal ions with respect to time is shown in Fig. 4. It can be concluded that the removal of metal ions or the adsorption is increasing with increase in the contact time. Initially, the adsorption was low but increases with time quickly. It also shows that the percent removal of $\mathrm{Cu}$ and $\mathrm{Zn}$ are 50 and $20 \%$ in $3 \mathrm{~h}$, which increased up to 70 and $22 \%$ in 12 and $9 \mathrm{~h}$, respectively. The less removal of $\mathrm{Zn}$ at equilibrium, indicating that more HA was needed to remove $\mathrm{Zn}$ ions. In the binary system, $41 \%$ of $\mathrm{Cu}$ and $16 \%$ of $\mathrm{Zn}$ were removed from the aqueous solution with equilibrium time of 12 and $9 \mathrm{~h}$, respectively. The less removal efficiency in binary system compared to the single metal system at equilibrium time is due to competitive sorption of heavy metals by HA. The equilibrium time for $\mathrm{Cu}$ and $\mathrm{Zn}$ removal reported by various researchers was compared with present study (Table 2). It was found that the contact time for HA is comparable.

\section{Effect of mass of adsorbent on heavy metal removal}

The effect of adsorbent dosage on heavy metal removal was analyzed by varying the dosage of HA and the results are shown in Fig. 5. It was found that the removal efficiency increases with the increase in HA dose. But the saturation of the adsorbent sites by the adsorption of the metal ions at the dosage levels of 0.4 and $0.7 \mathrm{~g} / 1$ with the removal efficiency of 99 and $98 \%$ for $\mathrm{Cu}$ and $\mathrm{Zn}$, respectively. In the binary system, the same percentage removal has been achieved with very high amount of HA $(0.9 \mathrm{~g} / \mathrm{l}$ for $\mathrm{Cu}$ and $3 \mathrm{~g} / \mathrm{l}$ for $\mathrm{Zn})$.

\section{Effect of $\mathrm{pH}$}

The uptake of $\mathrm{Cu}$ and $\mathrm{Zn}$ was examined over a $\mathrm{pH}$ range from 2.0 to 10 . The variation of the equilibrium uptake of $\mathrm{Cu}$ and $\mathrm{Zn}$ with the solution $\mathrm{pH}$ is shown in Fig. 6. It was observed from Fig. 6 that the amount of $\mathrm{Cu}$ and $\mathrm{Zn}$ removal by adsorption increased with an increase of $\mathrm{pH}$ up to about $\mathrm{pH} 6.0$ for $\mathrm{Cu}$ and $\mathrm{pH} 8$ for $\mathrm{Zn}$, respectively. Then the removal efficiency remains constant over the $\mathrm{pH}$ range of 6-10 for $\mathrm{Cu}$ and 8-10 for $\mathrm{Zn}$. However, $\mathrm{Cu}$ uptake was consistently higher than $\mathrm{Zn}$ uptake over the whole range of $\mathrm{pH}$ from 2.0 to 6. It is also noted that, for $\mathrm{pH} \mathrm{2,} \mathrm{the} \mathrm{metal}$ uptake for $\mathrm{Cu}$ increased at a much greater rate than that of $\mathrm{Zn}$. However, at the solution $\mathrm{pH}$ greater than 4.0, the uptakes of both $\mathrm{Cu}$ and $\mathrm{Zn}$ increased at a similar rate. The behavior observed at $\mathrm{pH} 2$ denotes a strong competition effect between the $\mathrm{Zn}$ and the $\mathrm{H}_{3} \mathrm{O}^{+}$ion for the active sites of the adsorbent. As a result, the $\mathrm{Zn}$ does not become adsorbed ( $\mathrm{G}^{\prime}$ omez-Tamayo et al. 2008).

\section{Adsorption kinetics}

It is known that adsorption process could be controlled with different kinds of mechanisms, such as mass transfer, 
Table 1 FTIR absorption band and corresponding functional groups

\begin{tabular}{lllllc}
\hline $\begin{array}{l}\text { Observed peak } \\
\left(\mathrm{cm}^{-1}\right)\end{array}$ & $\begin{array}{l}\text { \% Transmittance }(\mathrm{Cu} \\
\text { loaded })\end{array}$ & $\begin{array}{l}\text { \% Transmittance }(\mathrm{Zn} \\
\text { loaded })\end{array}$ & $\begin{array}{l}\% \text { Transmittance }(\mathrm{Cu} \text { and } \mathrm{Zn} \\
\text { loaded })\end{array}$ & $\begin{array}{l}\text { Peak range } \\
\left(\mathrm{cm}^{-1}\right)\end{array}$ & $\begin{array}{c}\text { Functional group } \\
3200-3600\end{array}$ \\
\hline 3560 & Increasing & Increasing & $\begin{array}{c}\text { Increasing } \\
\text { vibration }\end{array}$ \\
1608 & Increasing & Increasing & Increasing & $1300-1650$ & $\mathrm{CO}_{3}{ }^{2-}$ \\
1360 & Increasing & Increasing & Increasing & $1300-1650$ & $\mathrm{CO}_{3}{ }^{2-}$ \\
1422 & Increasing & Increasing & Increasing & $1300-1650$ & $\mathrm{CO}_{3}{ }^{2-}$ \\
1056 & No change & No change & No change & $900-1300$ & $\mathrm{PO}_{4}{ }^{3-}$ \\
612 & Increasing & Increasing & Increasing & $520-660$ & $\mathrm{PO}_{4}{ }^{3-}$ \\
566 & Increasing & Increasing & Increasing & $520-660$ & $\mathrm{PO}_{4}{ }^{3-}$ \\
\hline
\end{tabular}

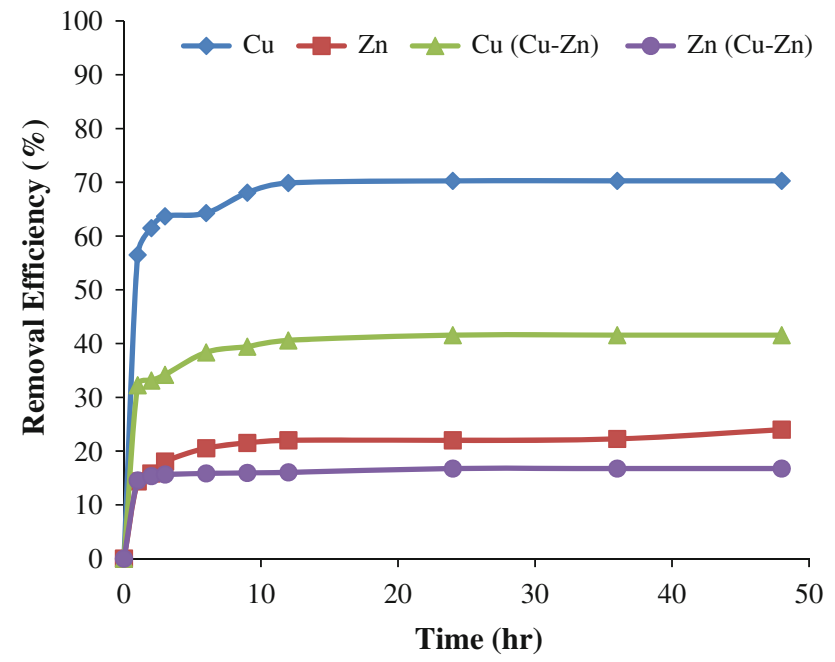

Fig. 4 Effect of contact time on removal of $\mathrm{Cu}$ and $\mathrm{Zn}$

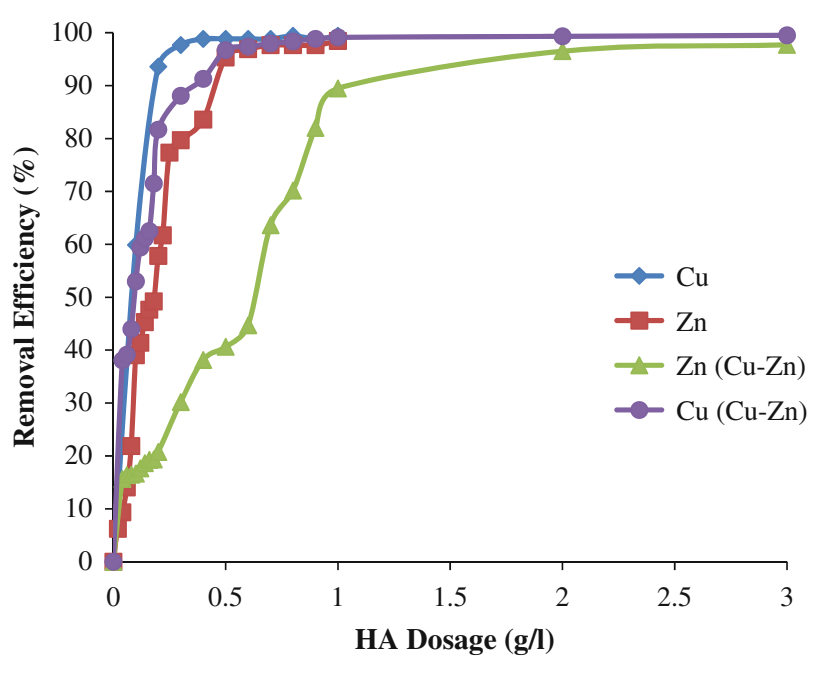

Fig. 5 Effect of dosage on removal of $\mathrm{Cu}$ and $\mathrm{Zn}$
Table 2 Comparison of contact time for $\mathrm{Cu}$ and $\mathrm{Zn}$ removal by various adsorbents

\begin{tabular}{|c|c|c|c|}
\hline \multirow[t]{2}{*}{ Adsorbent } & \multicolumn{2}{|c|}{ Equilibrium time (min) } & \multirow[t]{2}{*}{ Reference } \\
\hline & $\mathrm{Cu}$ & $\mathrm{Zn}$ & \\
\hline Ash & 120 & 90 & Al-Madhoun et al. (2005) \\
\hline Oil shale & 1,440 & 1,440 & Al-Asheh and Banat (2001) \\
\hline Fungal pellets of Aspergillus niger 405 & 300 & 300 & Filipovic-Kovacevic et al. (2000) \\
\hline HA & - & 1,440 & Go'mez del Rı'o et al. (2004) \\
\hline HA & 1,440 & 1,440 & Corami et al. (2007) \\
\hline Cork powder & - & 100 & Kanawade and Gaikwad (2011) \\
\hline Peanut hulls & 120 & 60 & Oliveira et al. (2010) \\
\hline Microwave incinerated rice husk ash & 720 & 1,080 & Kutty et al. (2011) \\
\hline HA & 720 & 540 & Present study \\
\hline
\end{tabular}

diffusion control, chemical reactions and particle diffusion. In order to clarify the adsorption process, several adsorption models were applied to evaluate the experimental data. For this purpose, Lagergren's pseudofirst-order kinetic model and pseudosecond-order kinetic model were considered and fitted with the experimental data. The pseudofirst-order equation is generally expressed as (Lagregren 1898), $\log \left(q_{e}-q_{t}\right)=\log \left(q_{e}\right)-\frac{k_{1}}{2.303} t$

where $q_{e}$ and $q_{t}$ are the adsorption capacity at equilibrium and at time $t$, respectively $(\mathrm{mg} / \mathrm{g}), k_{1}$ is the rate constant of pseudofirst-order adsorption $(1 / \mathrm{min})$.

The second-order Lagergren equation was given by (Ho and McKay 1999). It is expressed as 


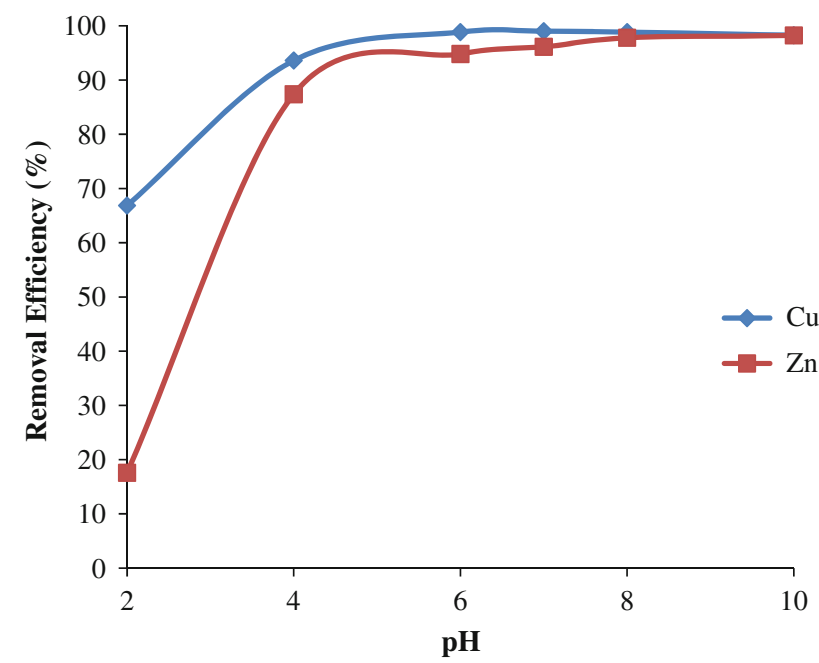

Fig. 6 Effect of $\mathrm{pH}$ on removal of $\mathrm{Cu}$ and $\mathrm{Zn}$

$\left(\frac{t}{q_{t}}\right)=\frac{l}{k_{2} q_{e}^{2}}+\frac{l}{q_{e}}(t)$,

where $k_{2}$ is the rate constant of pseudosecond-order adsorption $(\mathrm{g} / \mathrm{mg} / \mathrm{min})$.

Figures 7 and 8 show the plot of the first-order, and secondorder models for adsorption of heavy metals by the HA, respectively. Experimental and theoretically calculated adsorption capacities at equilibrium $\left(q_{e}\right)$ values and coefficients related to kinetic plots are listed in Table 3. It can be seen from Table 3 that the linear correlation coefficients for first order are not good when compared to the second-order model. These results suggest that the adsorption of $\mathrm{Cu}$ and $\mathrm{Zn}$ metal ions on HA is not pertaining to first-order reaction. It is evident from the results of second-order model that the correlation coefficients for $\mathrm{Cu}$ and $\mathrm{Zn}$ are very high and the experimental and theoretical $q_{e}$ values are in good match. These results suggest that the adsorption of the $\mathrm{Cu}$ and $\mathrm{Zn}$ ions in single and binary system on HA follows the second-order type kinetic reaction.

Rate limiting step in adsorption can be found out from intra particle diffusion model. The Weber and Morris (1963) intraparticle diffusion model is expressed as

$q_{t}=k_{\mathrm{id}} t^{1 / 2}+C$,

where $C$ is the intercept and $k_{\mathrm{id}}$ is the intraparticle diffusion rate constant $\left(\mathrm{mg} / \mathrm{g} \mathrm{min}^{0.5}\right)$, which can be evaluated from the slope of the linear plot of $q_{t}$ versus $t^{1 / 2}$. Intra particle diffusion model for $\mathrm{Cu}$ and $\mathrm{Zn}$ removal by $\mathrm{HA}$ in single and binary system is shown in Fig. 9. Figure 9 shows that the adsorption of $\mathrm{Cu}$ and $\mathrm{Zn}$ onto HA is multi-step process. It is having two regions. The first region is the instantaneous adsorption or external surface adsorption and the second region is the gradual adsorption stage where intraparticle diffusion is the rate limiting (Hammed 2009).
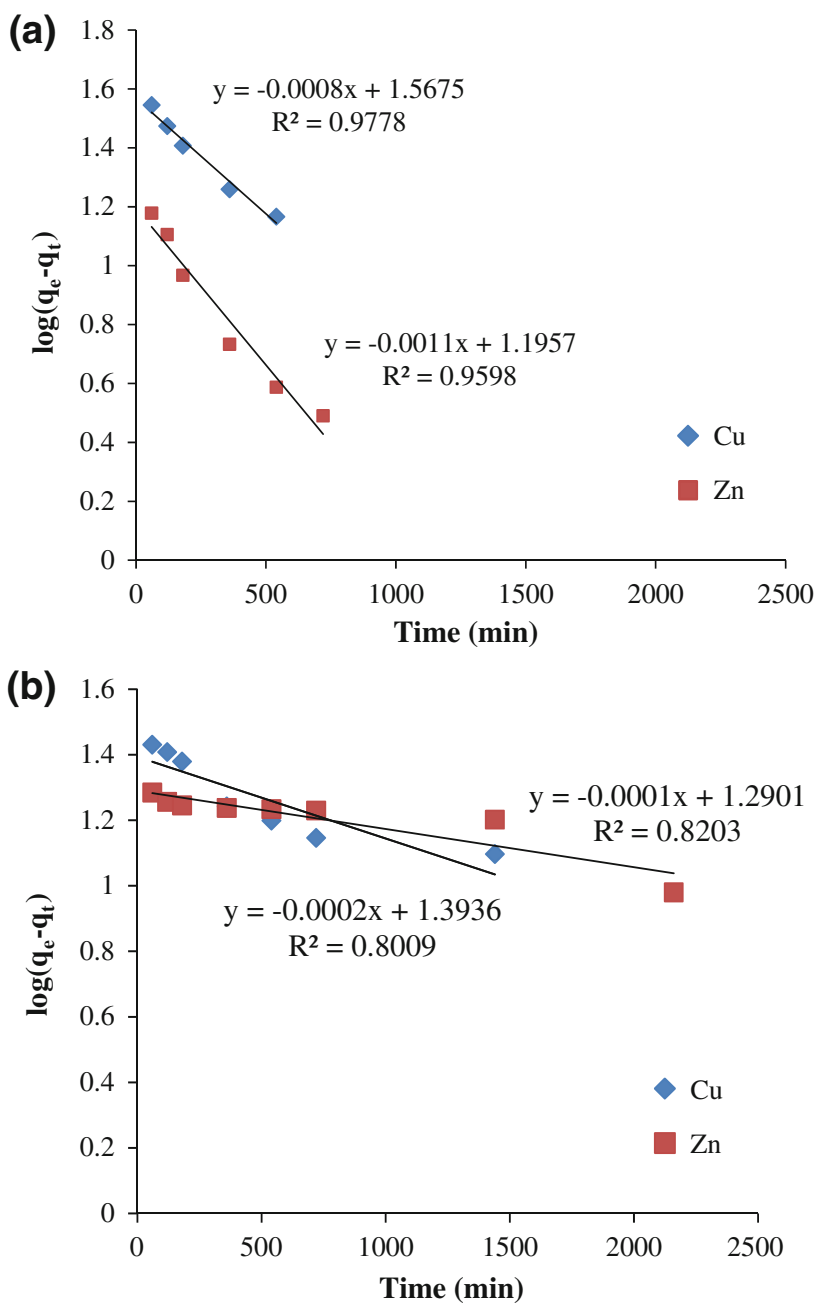

Fig. 7 Pseudofirst-order model plot for sorption of $\mathrm{Cu}$ and $\mathrm{Zn}$ by HA (a) single (b) binary system

Adsorption isotherms

The equilibrium relationships between adsorbent and adsorbate are best explained by sorption isotherms (Mittal et al. 2010). The experimental values are fitted with Freundlich and Langmuir isotherm equations. The applicability of the isotherm equations was compared by judging the correlation coefficients, $R^{2}$. The Langmuir isotherm is developed by assuming that a fixed number of adsorption sites are available, and that the adsorption is reversible. The Langmuir isotherm may be used when the adsorbent surface is homogeneous. The Langmuir isotherm is expressed as (Langmuir 1915)

$\frac{1}{X / M}=\frac{1}{q_{\max }}+\frac{1}{q_{\max } b} \frac{1}{C_{e}}$,

where $b$ is the constant that increases with increasing molecular size (mg/l), $q_{\max }$ is the amount adsorbed to form a complete monolayer on the surface $(\mathrm{mg} / \mathrm{g})$. 

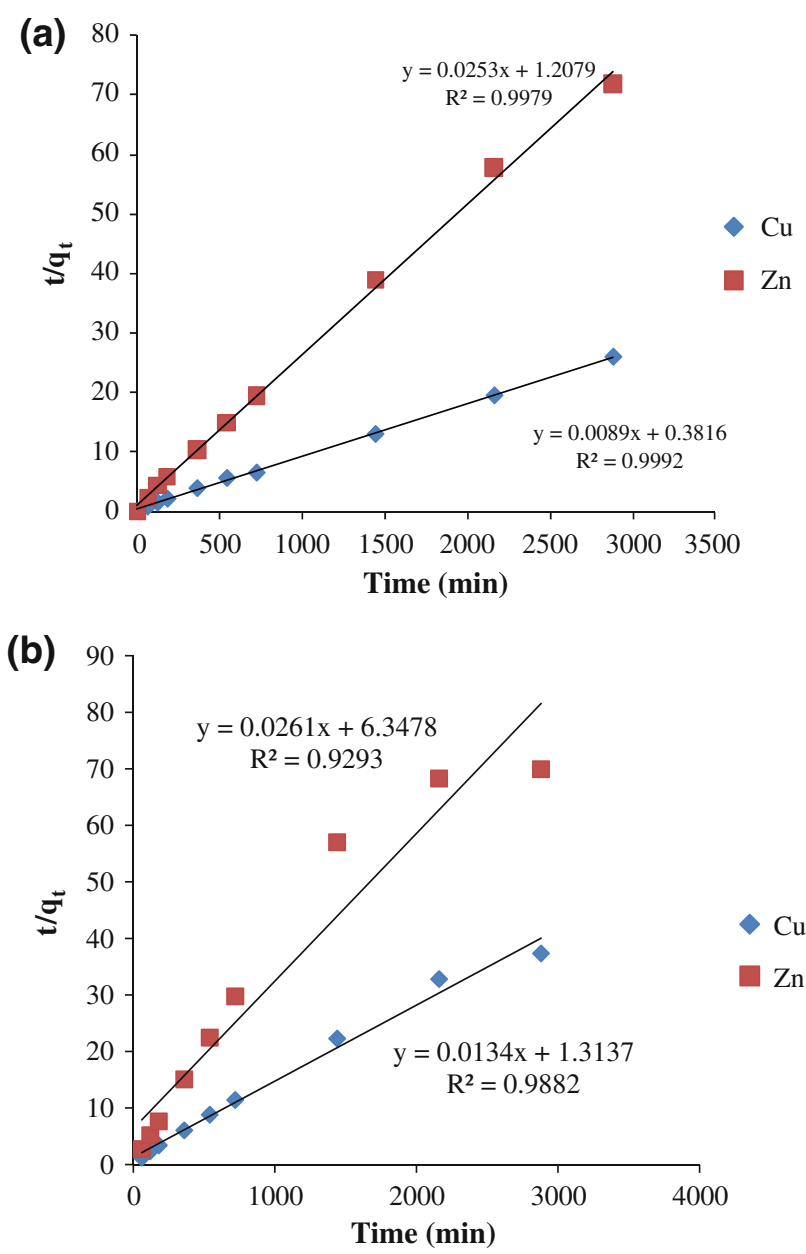

Fig. 8 Pseudosecond-order model plot for sorption of $\mathrm{Cu}$ and $\mathrm{Zn}$ by HA (a) single (b) binary system

The Freundlich isotherm is a result of the assumption that the adsorption occurs on a heterogeneous surface and non-uniform distribution of the heat of adsorption over the adsorbent surface takes place (Mittal et al. 2010).The Freundlich isotherm is expressed as (Freundlich 1906)

$\log q_{e}=\log k+\frac{1}{n} \log C_{e}$.

Where $q_{e}$ is the equilibrium adsorption uptake of heavy metal ions, in $\mathrm{mg} / \mathrm{g}, C_{\mathrm{e}}$ is the equilibrium concentration of heavy metal ions, in $\mathrm{mg} / \mathrm{l}$, and $k$ and $n$ are the Freundlich

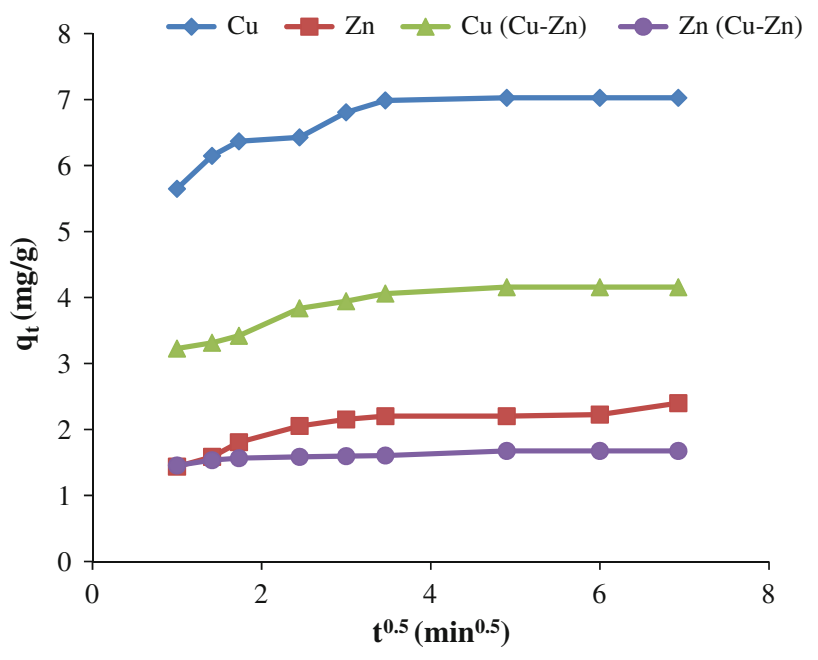

Fig. 9 Intraparticle diffusion model plots for the adsorption of $\mathrm{Cu}$ and $\mathrm{Zn}$ onto $\mathrm{HA}$

constants which are related to adsorption capacity and intensity, respectively.

The Langmuir and Freundlich isotherm plots are shown in Figs. 10 and 11, respectively. The isotherm constants were evaluated and are reported in Table 4. It was observed that the $R^{2}$ of Langmuir model is higher than the Freundlich's (except $\mathrm{Cu}$ in single system), which means that the adsorption belongs to the monolayer adsorption (Chen and Chen 2011). The Freundlich constant $n$ value lying in the range of 1-10 for single and binary system confirms the favorable conditions for adsorption (Shokoohi et al. 2009). The adsorption capacity of HA is $125 \mathrm{mg}$ of $\mathrm{Cu} / \mathrm{g}$, and $30.3 \mathrm{mg}$ of $\mathrm{Zn} / \mathrm{g}$.

In the $\mathrm{Cu}-\mathrm{Zn}$ system, competitive sorption between the aqueous heavy metals affected retention of metals by HA. $\mathrm{Zn}$ sorption $(13.16 \mathrm{mg}$ of $\mathrm{Zn} / \mathrm{g}$ ) was lower than that of $\mathrm{Cu}$ $(50 \mathrm{mg}$ of $\mathrm{Cu} / \mathrm{g})$. The same trend has been observed in single metal system. Preferential sorption is the adsorption rate limiting parameter in binary system. Preferential sorption depends on effective ionic radius. For $\mathrm{Zn}$ and $\mathrm{Cu}$ have effective ionic radius of 74 and $71 \mathrm{~A}$, respectively (Shannon 1976). Since both metals have almost same effective ionic radius, the removal from aqueous solution should be equal for both metals. In the present study, the removal of $\mathrm{Cu}$ and $\mathrm{Zn}$ are 99 and $98 \%$, respectively. This

Table 3 Adsorption kinetic model rate constants of $\mathrm{Cu}$ and $\mathrm{Zn}$ removal by $\mathrm{HA}$

\begin{tabular}{|c|c|c|c|c|c|c|c|c|}
\hline \multirow[t]{2}{*}{ System } & \multirow[t]{2}{*}{ Heavy metals } & \multicolumn{3}{|c|}{ Pseudo 1st-order co-efficients } & \multicolumn{3}{|c|}{ Pseudo 2nd-order coefficients } & \multirow[t]{2}{*}{$q_{e} \exp (\mathrm{mg} / \mathrm{g})$} \\
\hline & & $q_{e}(\mathrm{mg} / \mathrm{g})$ & $k_{1}(1 / \mathrm{min})$ & $R^{2}$ & $q_{e}(\mathrm{mg} / \mathrm{g})$ & $k_{2}(\mathrm{~g} / \mathrm{mg} / \mathrm{min})$ & $R^{2}$ & \\
\hline \multirow[t]{2}{*}{ Single } & $\mathrm{Cu}$ & 37 & 0.0018 & 0.97 & 113 & 0.012 & 0.99 & 110 \\
\hline & $\mathrm{Zn}$ & 15.69 & 0.0025 & 0.95 & 41 & 0.0004 & 0.99 & 40 \\
\hline \multirow[t]{2}{*}{ Binary } & $\mathrm{Cu}$ & 25 & 0.0004 & 0.80 & 75 & 0.00012 & 0.98 & 78 \\
\hline & $\mathrm{Zn}$ & 20 & 0.0002 & 0.82 & 39 & 0.00014 & 0.92 & 42 \\
\hline
\end{tabular}



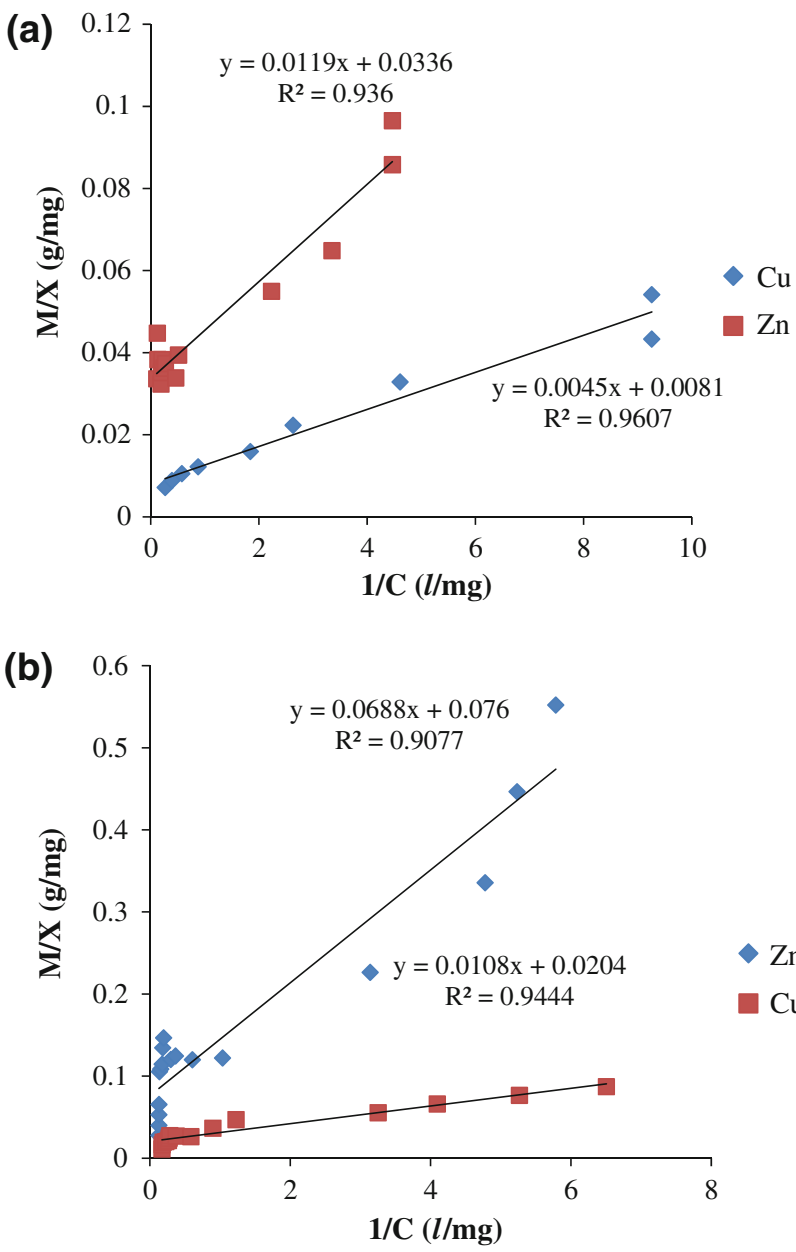

Fig. 10 Langmuir isotherm plot for sorption of $\mathrm{Cu}$ and $\mathrm{Zn}$ by $\mathrm{HA}$ (a) single (b) binary system

satisfies the above condition. But the adsorption capacity of $\mathrm{HA}$ is higher for $\mathrm{Cu}$ than $\mathrm{Zn}$. Similar results have been reported by Zacaria et al. (2002), Shawabkeh et al.(2004), Issabayeva and Aroua (2011) and Kutty et al. (2011). It was also inferred that the selectivity sequence of HA may be system specific which depended on the properties of the adsorbent and the experimental set-up used (Hui et al. 2005).

The maximum adsorption capacity of various adsorbents for $\mathrm{Cu}$ and $\mathrm{Zn}$ adsorption in single system together with the present study is given in Table 5. HA is found to have a relatively large adsorption capacity compared to other adsorbents. This indicates that HA can be considered as promising material for removing $\mathrm{Cu}$ and $\mathrm{Zn}$ from aqueous solution.

Sorption mechanism

Sorption of $\mathrm{Zn}$ and $\mathrm{Cu}$ undergoes two step processes. Rapid complexation of heavy metals on specific sites of HA
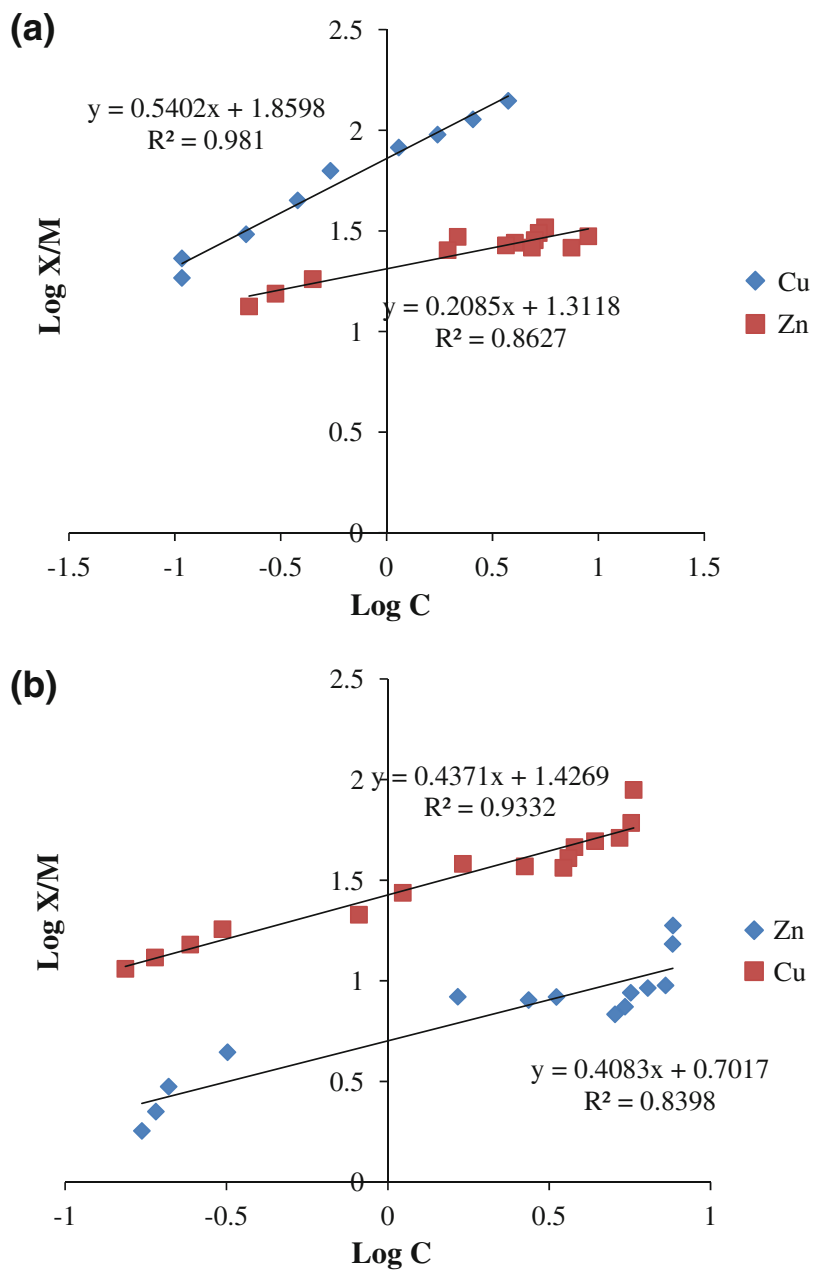

Fig. 11 Freundlich isotherm plot for sorption of $\mathrm{Cu}$ and $\mathrm{Zn}$ by $\mathrm{HA}$ (a) single (b) binary system

surface is the first step. A metal diffusion into the HA structure or to a heavy metal-containing HA formation is the second step in the sorption process (Corami et al. 2007). The sorption mechanisms have been inferred by the values of molar ratios $\left(Q_{\mathrm{s}}\right)$ of cations bound by $\mathrm{HA}$ to $\mathrm{Ca}$ desorbed from HA in single metal system and binary metal system (Corami et al. 2007) as given in Table 6. For the present study all the values of $Q_{\mathrm{s}}$ are less than one for single and binary system. This indicates that dissolution of HA and precipitation of new phosphate phase with lower cation to phosphate molar ratio occurs during sorption process (Corami et al. 2007). The increase in solution $\mathrm{Ca}$ increased with increasing metal disappearance was very high for $\mathrm{Cu}$ adsorption than that of $\mathrm{Zn}$ (Fig. 12). In the present study, $Q_{\mathrm{s}}$ is not equal to 1 indicates that the no possibility of ion exchange of cations between the HA and the solution (Corami et al. 2007). The adsorption energies (E) from Dubinin-Radushkevich isotherm plot (not shown) were $4.08,3.16,3.16$ and $2.3 \mathrm{~kJ} \mathrm{~mol}^{-1}$ for $\mathrm{Cu}, \mathrm{Zn}, \mathrm{Cu}$ $(\mathrm{Cu}-\mathrm{Zn})$ and $\mathrm{Zn} \quad(\mathrm{Cu}-\mathrm{Zn})$, respectively. For 
Table 4 Isotherm constants of $\mathrm{Cu}$ and $\mathrm{Zn}$ removal by HA

\begin{tabular}{|c|c|c|c|c|c|c|c|}
\hline \multirow[t]{2}{*}{ System } & \multirow[t]{2}{*}{ Heavy metals } & \multicolumn{3}{|c|}{ Langmuir coefficients } & \multicolumn{3}{|c|}{ Freundlich co-efficients } \\
\hline & & $q_{\max }(\mathrm{mg} / \mathrm{g})$ & $b(1 / \min )$ & $R^{2}$ & $k(\mathrm{mg} / \mathrm{g})$ & $n$ & $R^{2}$ \\
\hline \multirow[t]{2}{*}{ Single } & $\mathrm{Cu}$ & 125 & 2 & 0.96 & 72.41 & 1.852 & 0.981 \\
\hline & $\mathrm{Zn}$ & 30.3 & 3 & 0.936 & 20.5 & 4.807 & 0.862 \\
\hline \multirow[t]{2}{*}{ Binary } & $\mathrm{Cu}$ & 50 & 2 & 0.944 & 26.66 & 2.288 & 0.933 \\
\hline & $\mathrm{Zn}$ & 13.16 & 1.118 & 0.907 & 5.02 & 2.451 & 0.839 \\
\hline
\end{tabular}

Table 5 Comparison of maximum $\mathrm{Cu}$ and $\mathrm{Zn}$ adsorption capacity of various adsorbents

\begin{tabular}{|c|c|c|c|}
\hline \multirow[t]{2}{*}{ Adsorbent } & \multicolumn{2}{|c|}{$\begin{array}{l}\text { Capacity } \\
(\mathrm{mg} / \mathrm{g})\end{array}$} & \multirow[t]{2}{*}{ Reference } \\
\hline & $\mathrm{Cu}$ & $\mathrm{Zn}$ & \\
\hline Peanut hulls & 8 & 8.96 & Zacaria et al. (2002) \\
\hline Lignin & - & 95 & $\begin{array}{l}\text { Srivastava et al. } \\
\text { (1994) }\end{array}$ \\
\hline Palm shell activated carbon & 21 & 15 & $\begin{array}{r}\text { Issabayeva and } \\
\text { Aroua (2011) }\end{array}$ \\
\hline $\begin{array}{l}\text { Biomodified palm shell } \\
\text { activated carbon }\end{array}$ & 22 & 19 & $\begin{array}{l}\text { Issabayeva and } \\
\text { Aroua (2011) }\end{array}$ \\
\hline Chitosan-bound $\mathrm{Fe}_{3} \mathrm{O}_{4}$ & 21.5 & - & $\begin{array}{l}\text { Chang and Chen } \\
\text { (2005) }\end{array}$ \\
\hline Hydrated amorphous $\mathrm{TiO}_{2}$ & 84.79 & - & Kanna et al. (2005 \\
\hline Amberlite 200 & 88.90 & 85.60 & Zacaria et al. (2002) \\
\hline Cornstarch & 8.57 & 6.87 & Zacaria et al. (2002) \\
\hline Amberlite IRC-718 & 127.00 & 156.96 & Zacaria et al. (2002) \\
\hline Lewatit TP 207 & 85.09 & 89.60 & Zacaria et al. (2002) \\
\hline HA & 96 & 76.52 & Corami et al. (2007) \\
\hline HA & 125 & 30.3 & Present study \\
\hline
\end{tabular}

Table 6 Molar ratio values of $\mathrm{Cu}$ and $\mathrm{Zn}$ removal by HA

\begin{tabular}{lllll}
\hline System & Metal & $\begin{array}{l}\text { Metal disappearance } \\
(\mathrm{mg} / \mathrm{l})\end{array}$ & $\begin{array}{l}\text { Solution } \\
\mathrm{Ca}(\mathrm{mg} / \mathrm{l})\end{array}$ & $\begin{array}{l}\text { Molar ratio } \\
\left(Q_{\mathrm{S}}\right)\end{array}$ \\
\hline Single & $\mathrm{Cu}$ & 9.88 & 12 & 0.823 \\
& $\mathrm{Zn}$ & 9.76 & 14 & 0.666 \\
Binary & $\mathrm{Cu}-\mathrm{Zn}$ & 19.65 & 38 & 0.515 \\
\hline
\end{tabular}

$E<8 \mathrm{kJmol}^{-1}$, indicates that physisorption dominates the sorption mechanism (Argun et al. 2007). Therefore, it can be concluded that no ion-exchange between heavy metal adsorbed and $\mathrm{Ca}$ released into the solution.

\section{Conclusions}

The present study has demonstrated that HA has the adsorption capacity for removal of $\mathrm{Cu}$ and $\mathrm{Zn}$ from an aqueous solution. The equilibrium time for $\mathrm{Cu}$ and $\mathrm{Zn}$ removal was found as 12 and $9 \mathrm{~h}$ in both systems. The
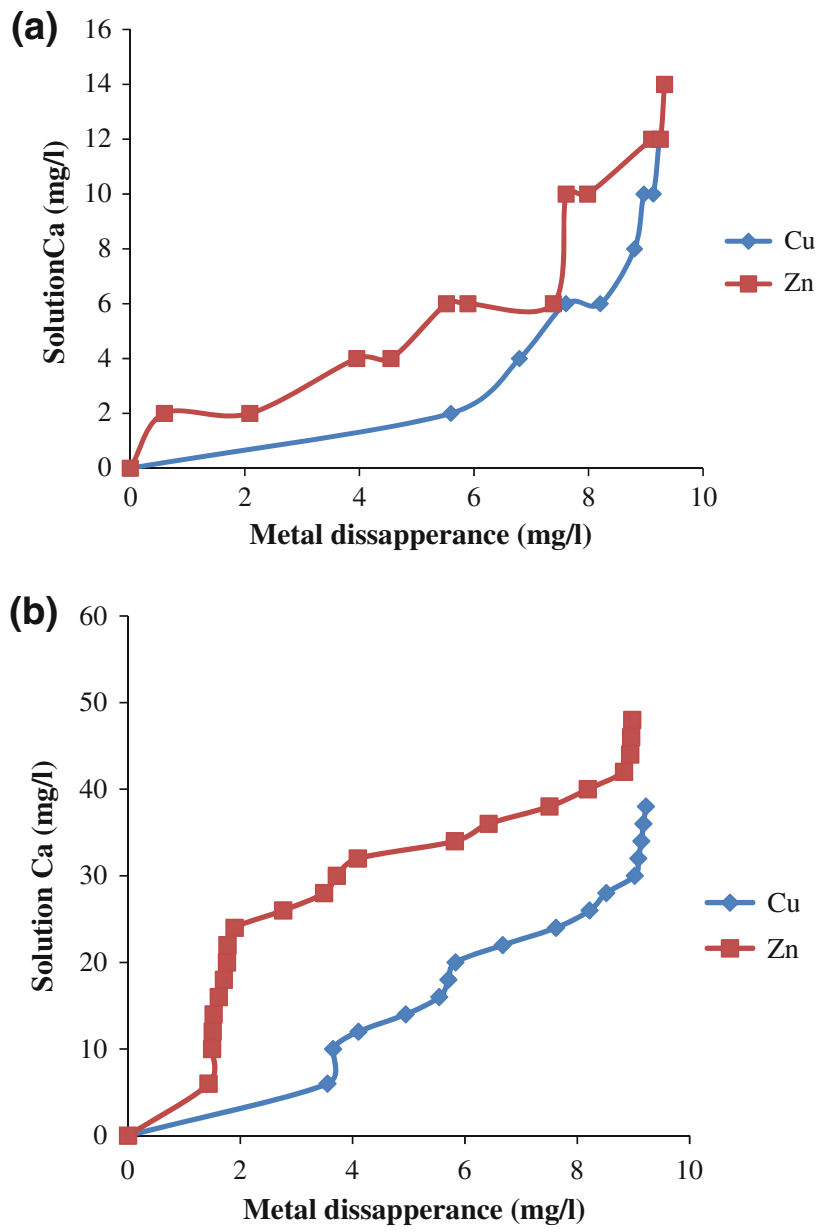

Fig. 12 Metal disappearance for (a) single (b) binary system

optimum dose of HA was found to be 0.4 and $0.7 \mathrm{~g} / 1$ for $\mathrm{Cu}$ and $\mathrm{Zn}$ with the removal efficiencies of 99 and $98 \%$, respectively for single system. Similar efficiency was obtained for HA dosage of $0.9 \mathrm{~g} / \mathrm{l}$ for $\mathrm{Cu}$ and $3 \mathrm{~g} / \mathrm{l}$ for $\mathrm{Zn}$ in binary system. The maximum removal of $\mathrm{Cu}$ and $\mathrm{Zn}$ were occurred at $\mathrm{pH}$ of 6 and 8 , respectively. Adsorption of $\mathrm{Cu}$ and $\mathrm{Zn}$ onto HA followed the pseudosecond-order kinetic model. Langmuir model fitted the experimental data better than Freundlich model, even though adsorption is favorable for Freundlich isotherm. The removal capacity of HA was found to be $125 \mathrm{mg}$ of $\mathrm{Cu} / \mathrm{g}, 30.3 \mathrm{mg}$ of $\mathrm{Zn} / \mathrm{g}$ in single system and $50 \mathrm{mg}$ of $\mathrm{Cu} / \mathrm{g}, 15.16 \mathrm{mg}$ of $\mathrm{Zn} / \mathrm{g}$ in binary 
system. The results showed that HA is a good adsorbent for the removal of $\mathrm{Cu}$ and $\mathrm{Zn}$ from aqueous solutions.

Open Access This article is distributed under the terms of the Creative Commons Attribution License which permits any use, distribution, and reproduction in any medium, provided the original author(s) and the source are credited.

\section{References}

Aklil M, Mouflih M, Sebti S (2004) Removal of heavy metal ions from water by using calcined phosphate as a new adsorbent. J Hazard Mater 112:183-190

Al-Asheh S, Banat F (2001) Adsorption of copper and zinc by oil shale. Environ Geol 40(6):693-698

Al-Madhoun WA, Hasnain Isa M, Ramli NA, Adlan MN, Hameed $\mathrm{BH}$, Farooqi $\mathrm{IH}$ (2005) $\mathrm{Cu}$ and $\mathrm{Zn}$ removal by adsorption using ash from palm oil factory. Proceeding of the international conference on water: rights and values, Ramllah, Palestine

Argun ME, Dursun S, Ozdemir C, Karatas M (2007) Heavy metal adsorption by modified oak sawdust: thermodynamics and kinetics. J Hazard Mater 141:77-85

Bayrak Y, Yesilogu Y, Gecgel U (2006) Adsorption behavior of $\mathrm{Cr}(\mathrm{VI})$ on activated hazelnut shell ash and activated bentonite. Microporous Mesoporous Mater 91:107-110

Benhima H, Chiban M, Sinan F, Seta P, Persin M (2008) Removal of $\mathrm{Cd}(\mathrm{II})$ and $\mathrm{Pb}(\mathrm{II})$ ions from aqueous solution by adsorption onto micro-particles of dry plants. Coll Surf B Biointerfaces 61:10-16

Chang YC, Chen DH (2005) Preparation and adsorption properties of monodisperse chitosan-bound $\mathrm{Fe}_{3} \mathrm{O}_{4}$ magnetic nanoparticles for removal of $\mathrm{Cu}(\mathrm{II})$ ions. J Coll Interface Sci 283:446-451

Chauhan D, Sankararamakrishnan N (2011) Modeling and evaluation on removal of hexavalent chromium from aqueous systems using fixed bed column. J Hazard Mater 185:55-62

Chen YH, Chen YD (2011) Kinetic study of $\mathrm{Cu}$ (II) adsorption on nanosized $\mathrm{BaTiO}_{3}$ and $\mathrm{SrTiO}_{3}$ photocatalysts. J Hazard Mater 185:168-173

Chiban M, Lehutu G, Sinan F, Carja G, (2009) Arsenate removal by Withania frutescens plant from the south-western Morocco. Environ Eng Manag J 8(6):1377-1383

Chiban M, Soudani A, Sinan F, Persin M (2011a) Single, binary and multi-component adsorption of some anions and heavy metals on environmentally friendly Carpobrotus edulis plant. Coll Surf B Biointerfaces 82:267-276

Chiban M, Soudani A, Sinan F, Persin M (2011b) Characterization and application of dried plants to remove heavy metals, nitrate and phosphate ions from industrial wastewaters in a batch system. CLEAN Soil, Air, Water, 39:376-383

Chiban M, Soudani A, Sinan F, Persin M (2011c) Wastewater treatment by batch adsorption method onto micro-particles of dried Withania frutescens plant as a new adsorbent. J Environ Manag. doi:10.1016/j.jenvman.2011.06.044

Chiban M, Carja G, Lehutu G, Sinan F (2012) Equilibrium and thermodynamic studies for the removal of $\mathrm{As}(\mathrm{V})$ ions from aqueous solution using dried plants as an adsorbents. Arabian J Chem. doi:10.1016/j.arabjc.2011.10.002

Chu HC, Chen KM (2002) Reuse of activated sludge biomass II. The rate processes for the adsorption of basic dyes on biomass. Process Biochem 37:1129-1134

Corami A, Mignardi S, Ferrini V (2007) Copper and zinc decontamination from single- and binary-metal solutions using hydroxyapatite. J Hazard Mater 146:164-170

Corami A, D'Acapito A, Mignardi S, Ferrini V (2008) Removal of Cu from aqueous solutions by synthetic hydroxyapatite: EXAFS investigation. Mater Sci Eng, B 149:209-213
Eckenfelder WW Jr (2000) Industrial water pollution control, 3rd edn. Mcgraw-Hill, Singapore

Feng N, Guo X, Liang S, Zhu Y, Liu J (2011) Biosorption of heavy metals from aqueous solutions by chemically modified orange peel. J Hazard Mater 185:49-54

Filipovic-Kovacevic Z, Sipos L, Briski F (2000) Biosorption of chromium, copper, nickel and zinc ions onto fungal pellets of Aspergillus niger 405 from aqueous solutions. Food Technol Biotechnol 38(3):211-216

Freundlich H (1906) Ü ber die adsorption in lösungen [Adsorption in solution]. Z Phys Chem 57:384-470

G'omez-Tamayo MDM, Macias-Garcia A, Diaz Diez MA, CuerdaCorrea EM (2008) Adsorption of $\mathrm{Zn}$ (II) in aqueous solution by activated carbons prepared from evergreen oak (Quercus rotundifolia L.). J Hazard Mater 153:28-36

Go'mez del Rı'o JA, Morando PJ, Cicerone DS (2004) Natural materials for treatment of industrial effluents: comparative study of the retention of $\mathrm{Cd}, \mathrm{Zn}$ and $\mathrm{Co}$ by calcite and hydroxyapatite. Part I: batch experiments. J Environ Manag 71:169-177

Gupta A, Bhatti HS, Kumar D, Verma NK, Tandon RP (2006) Nano and bulk crystals of Zno: synthesis and characterization. Digest $\mathrm{J}$ Nanomater Biostructures 1(1):1-9

Hammed BH (2009) Spent tea leaves: a new non-conventional and low-cost adsorbent for removal of basic dye from aqueous solutions. J Hazard Mater 161:753-759

Hashimoto Y, Sato T (2007) Removal of aqueous lead by poorlycrystalline hydroxyapatites. Chemosphere 69:1775-1782

Ho YS, McKay G (1999) Pseudo-second-order model for sorption processes. Process Biochem 34:451-465

Hui KS, Chao CYH, Kot SC (2005) Removal of mixed heavy metal ions in wastewater by zeolite $4 \mathrm{~A}$ and residual products from recycled coal fly ash. J Hazard Mater B127:89-101

Issabayeva G, Aroua MK (2011) Removal of copper and zinc ions onto biomodified palm shell activated carbon. World Acad Sci Eng Technol 76:259-262

Kanawade SM, Gaikwad RW (2011) Removal of zinc ions from industrial effluent by using cork powder as adsorbent. Int J Chem Eng Appl 2(3):199-201

Kanna M, Wongnawa S, Sherdshoopongse P, Boonsin P (2005) Adsorption behavior of some metal ions on hydrated amorphous titanium dioxide surface. Songklanakarin J Sci Technol 27(5):1017-1026

King P, Anuradha K, Beena Lahari S, Prasanna Kumar Y, Prasad VSRK (2008) Biosorption of zinc from aqueous solution using Azadirachta indica bark: equilibrium and kinetic studies. J Hazard Mater 152(1):324-329

Kutty SRM, Ngatenah SNI, Johan NA, Amat KAC (2011) Removal of $\mathrm{Zn}(\mathrm{II}), \mathrm{Cu}(\mathrm{II})$, chemical oxygen demand (COD) and colour from anaerobically treated palm oil mill effluent (POME) using microwave incinerated rice husk ash (MIRHA). Int Conf Environ Ind Innov IPCBEE 12:90-94

Lagregren S (1898) About the theory of so-called adsorption of soluble substances. Kungliga Svenska Vetenskapsakademiens Handlingar 24:1-39

Langmuir I (1915) Chemical reactions at low pressures. J Am Chem Soc 27:1139-1143

Lusvardi G, Malavasi G, Menabue L, Saladini M (2002) Removal of cadmium ion by means of synthetic hydroxyapatite. Waste Manag 22:853-857

Manjubala I, Sivakumar M, Najma Nikkath S (2001) Synthesis and characterisation of hydroxy/fluoroapatite solid solution. J Mater Sci 36:5481-5486

Mavropoulos E, Rossi AM, Costa AM, Perez CAC, Moreira JC, Saldanha M (2002) Studies on the mechanisms of lead immobilization by hydroxyapatite. Environ Sci Technol 36:1625-1629 
Mittal A, Mittal J, Malviya A, Kaur D, Gupta VK (2010) Adsorption of hazardous dye crystal violet from wastewater by waste materials. J Coll Interface Sci 343:463-473

Mohan D, Singh KP (2002) Single- and multi-component adsorption of cadmium and zinc using activated carbon derived from bagasse-an agricultural waste. Water Res 36:2304-2318

Montazer-Rahmati MM, Rabbani P, Abdolali A, Keshtkar AR (2011) Kinetics and equilibrium studies on biosorption of cadmium, lead, and nickel ions from aqueous solutions by intact and chemically modified brown algae. J Hazard Mater 185:401-407

Mulligan CN, Yong RN, Gibbs BF (2001) Remediation technologies for metal-contaminated soils and groundwater: an evaluation. Eng Geol 60:193-207

Oliveira FD, Soares AC, Freitas OM, Figueiredo SA (2010) Copper, nickel and zinc removal by peanut hulls: batch and column studies in mono, tri-component systems and with real effluent. GlobNest J 12(2):206-214

Ozer A, Pirinççi HB (2006) The adsorption of $\mathrm{Cd}(\mathrm{II})$ ions on sulphuric acid treated wheat bran. J Hazard Mater 137:849-855

Ramesh ST, Gandhimathi R, Nidheesh PV, Nagendra Badabhagni, Bharathi KS (2011a) Breakthrough data analysis of adsorption of Cd (II) on coir pith column. Electron J Environ Agric Food Chem 10(7):2487-2505

Ramesh ST, Gandhimathi R, Nagendra Badabhagni, Nidheesh PV (2011b) Removal of Cd (II) from aqueous solution by adsorption onto coir pith, an agricultural solid waste: batch experimental study. Environ Eng Manag J 10(11):1667-1673

Rehman I, Bonfield W (1997) Characterization of hydroxyapatite and carbonated apatite by photo acoustic FTIR spectroscopy. J Mater Sci Mater Med 8:1-4

Saeed A, Iqbal M (2003) Bioremoval of cadmium from aqueous solution by black gram husk (Cicer arientinum). Water Res 37:3472-3480
Shannon RD (1976) Crystal physics, diffraction, theoretical and general crystallography. Acta Crystallogr Sect A 32:751-767

Shashkova IL, Rat'ko AI, Kitikova NV (1999) Removal of heavy metal ions from aqueous solutions by alkaline-earth metal phosphates. Coll Surf A Physicochem Eng Aspects 160:207-215

Shawabkeh R, Al-Harahsheh A, Al-Otoom A (2004) Copper and zinc sorption by treated oil shale ash. Sep Purif Technol 40:251-257

Shokoohi R, Saghi MH, Ghafari HR, Hadi M (2009) Biosorption of iron from aqueous solution by dried biomass of activated sludge. Iranian J Environ Health Sci Eng 6(2):107-114

Sitting M (1981) Handbook of toxic and hazardous chemicals. Noyes Publications, Park Ridge

Srivastava SK, Singh AK, Sharma A (1994) Studies on the uptake of lead and zinc by lignin obtained from black liquor-a paper industry waste material. Environ Technol 15:353-361

Suzuki T, Ishigaki K, Miyake M (1984) Synthetic HAs as inorganic cation exchangers exchange characteristics of lead ions $\left(\mathrm{Pb}^{2+}\right)$. J Chem Soc Faraday Transm 80:3157-3165

Valdman E, Erijman L, Pessoa FLP, Leite SG (2001) Continuous biosorption of $\mathrm{Cu}$ and $\mathrm{Zn}$ by immobilized waste biomass Sargassum sp. Process Biochem 36:869-873

Vega ED, Pedregosa JC, Narda GE (2009) Adsorption of oxovanadium (IV) from aqueous solutions by nanoparticulated hydroxyapatite thermodynamic and kinetic study. J Argent Chem Soc 97:1-12

Weber WJ, Morris JC (1963) Kinetics of adsorption on carbon from solution. J Sanit Eng Div Am Soc Chem Eng 89:31-59

Zacaria R, Gerente C, Andres Y, Cloirec PL (2002) Adsorption of several metal ions onto low-cost biosorbent: kinetic and equilibrium studies. Environ Sci Technol 36:2067-2073 